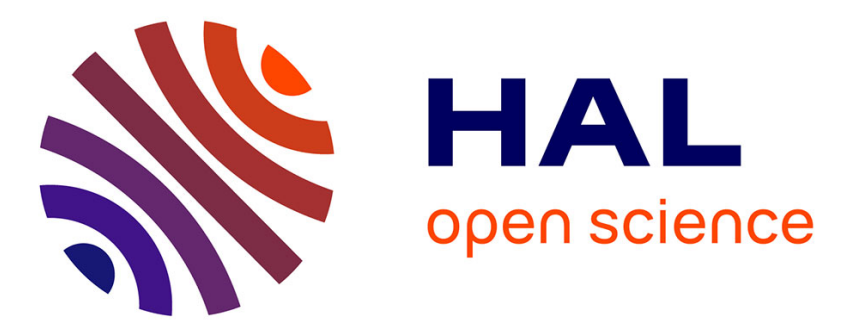

\title{
Detecting climatic signals in an anthropogenically disturbed catchment: The late-Holocene record from the Petit Lac d'Annecy, French Alps.
}

Richard T. Jones, Liam J. Reinhardt, John A. Dearing, Darren Crook, Richard C. Chiverrell, Katharine Welsh, Elisabeth Lallier-Vergès

\section{To cite this version:}

Richard T. Jones, Liam J. Reinhardt, John A. Dearing, Darren Crook, Richard C. Chiverrell, et al.. Detecting climatic signals in an anthropogenically disturbed catchment: The late-Holocene record from the Petit Lac d'Annecy, French Alps.. The Holocene, 2013, 23 (9), pp.1329-1339. 10.1177/0959683613486940 . insu-00854043

\section{HAL Id: insu-00854043 \\ https://hal-insu.archives-ouvertes.fr/insu-00854043}

Submitted on 26 Mar 2021

HAL is a multi-disciplinary open access archive for the deposit and dissemination of scientific research documents, whether they are published or not. The documents may come from teaching and research institutions in France or abroad, or from public or private research centers.
L'archive ouverte pluridisciplinaire HAL, est destinée au dépôt et à la diffusion de documents scientifiques de niveau recherche, publiés ou non, émanant des établissements d'enseignement et de recherche français ou étrangers, des laboratoires publics ou privés. 


\section{ORE Open Research Exeter}

\section{TITLE}

Detecting climatic signals in an anthropogenically disturbed catchment: The late-Holocene record from the Petit Lac d'Annecy, French Alps

\section{AUTHORS}

Jones, RT; Reinhardt, LJ; Dearing, JA; et al.

\section{JOURNAL}

Holocene

\section{DEPOSITED IN ORE}

13 February 2018

This version available at

http://hdl.handle.net/10871/31469

\section{A NOTE ON VERSIONS}

The version presented here may differ from the published version. If citing, you are advised to consult the published version for pagination, volume/issue and date of 
The Holocene

\section{Detecting climatic signals in an anthropogenically disturbed catchment: The Late Holocene record from the Lac d'Annecy.}

\begin{tabular}{|c|c|}
\hline Journal: & The Holocene \\
\hline Manuscript ID: & HOL-12-0038.R1 \\
\hline Manuscript Type: & Paper \\
\hline Date Submitted by the Author: & $\mathrm{n} / \mathrm{a}$ \\
\hline Complete List of Authors: & $\begin{array}{l}\text { Jones, Richard; University of Exeter, Geography } \\
\text { Reinhardt, Liam; University of Exeter, Geography } \\
\text { Dearing, John; University of Southampton, School of Geography; } \\
\text { Crook, Darren; University of Hertfordshire, Geography } \\
\text { Chiverrell, Richard; University of Liverpool, Geography } \\
\text { Welsh, Katharine; University of Chester, Geography } \\
\text { Verges, Elisabeth; CNRS, Matière Organique }\end{array}$ \\
\hline Keywords: & $\begin{array}{l}\text { Lac d'Annecy, sedimentation rates, anthropocene, soil erosion, landscape } \\
\text { dynamics, signal shredding }\end{array}$ \\
\hline Abstract: & $\begin{array}{l}\text { Historical and documentary records from the Lac d'Annecy, indicate that } \\
\text { human activities have been the dominant 'geomorphic process' shaping the } \\
\text { catchment during the late Holocene, with deforestation, agriculture and } \\
\text { artificial drainage profoundly affecting both the pace and spatial } \\
\text { distribution of soil erosion. The impact of past climatic change on the } \\
\text { evolution of the catchment is less certain due to the lack of long-term } \\
\text { climate records for the site. Previous attempts to use the sediment record } \\
\text { from the lake to investigate the role past climate change may have played } \\
\text { was hampered by the difficulty in isolating and disentangling the climatic } \\
\text { signal preserved within the archive due to overprinting of human activity. } \\
\text { This is a common problem in regions with a long history of human activity } \\
\text { in the landscape. In this study we use a range of advanced statistical } \\
\text { techniques to assess the relative importance of climate in driving landscape } \\
\text { dynamics. The statistical analysis is carried out on an updated high- } \\
\text { resolution palaeo-environmental data set from the Petit Lac. The results of } \\
\text { the statistical analysis indicate for the first time that regional climate } \\
\text { phenomena such as the Atlantic multi-decadal oscillation are partly } \\
\text { responsible for landscape dynamics at Lac d'Annecy throughout the late } \\
\text { Holocene. We find that the Lac d'Annecy landscape typically requires } \\
\text { decades, or longer, to respond to changes in precipitation, reflecting the } \\
\text { stochastic nature of river sediment storage and transport. The use of a } 4 \\
\text { year integrated lake core records effectively attenuates the 'signal } \\
\text { shredding' effect of shorter-term internally generated sediment transport } \\
\text { processes. Nonetheless, the lake record of climatically-induced } \\
\text { geormorphic process-responses is weak compared to the pervasive impact } \\
\text { of human activities. }\end{array}$ \\
\hline
\end{tabular}




1
2
3
4
5
6
7
8
9
10
11
12
13
14
15
16
17
18
19
20
21
22
23
24
25
26
27
28
29
30
31
32
33
34
35
36
37
38
39
40
41
42
43
44
45
46
47
48
49
50
51
52
53
54
55
56
57
58
59
60

SCHOLARONE $^{\text {m }}$

Manuscripts

http://mc.manuscriptcentral.com/holocene 


\begin{abstract}
Detecting climatic signals in an anthropogenically disturbed catchment: The Late Holocene record from the Lac d'Annecy
\end{abstract}

\author{
Jones R.T. ${ }^{1}$, Reinhardt LW. ${ }^{1}$, Dearing, J.A. ${ }^{2}$ Crook D ${ }^{3}$, Chiverrell, R. ${ }^{4}$ Welsh. K ${ }^{5}$, Verges, $E^{6}$. \\ ${ }^{1}$ Geography, College of Life and Environmental Science, University of Exeter, Exeter, EX4 4RJ, \\ UK. \\ ${ }^{2}$ Geography and Environment, University of Southampton, SO17 1BJ, UK \\ ${ }^{3}$ Department of Geography, University of Hertfordshire, Herts, AL10 9AB, UK. \\ ${ }^{4}$ Department of Geography, University of Liverpool, Liverpool, L69 7ZT, UK. \\ ${ }^{5}$ Department of Geography and Development Studies, University of Chester, Chester, CH1 4BJ, \\ UK \\ ${ }^{6}$ Institut des Sciences de la Terre d'Orléans - ISTO, Université Orléans, France.
}

\begin{abstract}
Historical and documentary records from the Lac d'Annecy, indicate that human activities have been the dominant 'geomorphic process' shaping the catchment during the late Holocene, with deforestation, agriculture and artificial drainage profoundly affecting both the pace and spatial distribution of soil erosion. The impact of past climatic change on the evolution of the catchment is less certain due to the lack of long-term climate records for the site. Previous attempts to use the sediment record from the lake to investigate the role past climate change may have played was hampered by the difficulty in isolating and disentangling the climatic signal preserved within the archive due to overprinting of human activity. This is a common problem in regions with a
\end{abstract}


long history of human activity in the landscape. In this study we use a range of advanced statistical techniques to assess the relative importance of climate in driving landscape dynamics. The statistical analysis is carried out on an updated high-resolution palaeo-environmental data set from the Petit Lac. The results of the statistical analysis indicate for the first time that regional climate phenomena such as the Atlantic multi-decadal oscillation are partly responsible for landscape dynamics at Lac d'Annecy throughout the late Holocene. We find that the Lac d'Annecy landscape typically requires decades, or longer, to respond to changes in precipitation, reflecting the stochastic nature of river sediment storage and transport. The use of a 4 year integrated lake core records effectively attenuates the 'signal shredding' effect of shorter-term internally generated sediment transport processes. Nonetheless, the lake record of climaticallyinduced geormorphic process-responses is weak compared to the pervasive impact of human activities.

Keywords

Lac d'Annecy, sedimentation rates, anthropocene, soil erosion, signal shredding, lake-catchment 


\section{Introduction}

The post-glacial period is characterised by significant changes in climate, changes that are now accelerating due to human activities. Until recently it was widely accepted that researchers could observe the impact of these changes in the sediment record; indeed this is the basis of much palaeo-environmental research (e.g. Dearing and Oldfield 2002; Dearing and Jones 2003; Dearing et al., 2006). However, this simple relationship between climatic-cause and depositional-effect has been challenged in various modelling studies (Dearing and Zolitschka 1999; Jerolmack and Paola, 2010; Coulthard and Van de Wiel 2007; Van de Wiel and Coulthard, 2010; Ganti et al., 2011). These studies argue that sediment transport through catchments is controlled by internally generated critically self-organised (SOC) processes that act as non-linear filters that 'shred' externally generated signals such as climate change. Part of this filtering process is the 'smearing' effect of stochastic sediment transport. Rivers typically respond to periods of accelerated erosion through increasing local deposition that can persist for decades or even centuries in the case of large landslides. Depending on a host of climatic and tectonic factors these deposits are gradually eroded and transported out of the system but this too can take centuries (Benda and Dunne, 1997). Thus stochastic sediment transport may lead to a pattern of lake sedimentation that simply reflects the internal dynamics of a catchment rather than environmental conditions (Coulthard and Van de Wiel 2007; Van de Wiel and Coulthard, 2010). Also critical is the magnitude of the climate or environmental signal. Signals of sufficient magnitude or sufficiently low frequency should be preserved in the stratigraphic record (Jerolmack and Paola, 2010) though what constitutes 'low' frequency remains ambiguous as 'signal shredding' has only been explored in unscaled or shortterm (daily) numerical and physical models (Coulthard and Van de Wiel 2007; Van de Wiel and Coulthard, 2010; Jeromack and Paola, 2010). In recent centuries (and perhaps millennia) a far more pervasive and intensive unnatural 'signal filtering' mechanism has arisen, namely human 
land-use. Activities such as agriculture and mining are now the dominant mechanisms of erosion and sediment transport worldwide (Hooke, 2000; Wilkinson and McElroy, 2007; Reinhardt et al., 2010). It seems logical to assume that human activities will also 'shred' environmental signals but exactly how and over what timescales is unknown.

Here we attempt to discern a climate signal from lake sediment proxies of geomorphic processes in the Lac d'Annecy catchment which has been subject to varying landuse over the late Holocene in order to explore whether non-linear geomorphic processes are as pervasive a signal shredding mechanism as recently claimed. The impact of land use change on geomorphic processes is already well established for this catchment (Dearing, 1979, 2001; Higgitt et al., 1991; Thorndycraft et al., 1998; Crook et al., 2002, 2004, 2011; Foster et al., 2003; Dearing et al., 2001; Noel et al., 2001) but previous studies have been unable to discern the impact of climate change in the lake sediment record. Here we analyze a new high-resolution dataset and apply a novel statistical approach to identify the impact of precipitation change in driving catchment dynamics during the late Holocene. We focus on precipitation as our climate proxy because data is available for the late Holocene and it is the climatic forcing mechanism most closely associated with the (non-linear) processes of sediment transport and deposition in a catchment.

\section{The Petit Lac d'Annecy catchment}

The Lac d'Annecy is located in the Haute Savoie region of Eastern France (Lat $45^{\circ} 48^{\prime} \mathrm{N}$; Long $6^{\circ} 8^{\prime} \mathrm{E}$ ) within the foreland of the French Alps (Figure 1). The lake is oligotrophic and lies at an altitude of $460 \mathrm{~m}$, within a traverse tectonic valley that reaches a maximum altitude of $\sim 2250$ m. The lake consists of two basins the Grand Lac $\left(20.25 \mathrm{~km}^{2}\right)$ and Petit Lac $\left(6.25 \mathrm{~km}^{2}\right)$, which have a combined surface area of $\sim 26.5 \mathrm{~km}^{2}$ and a catchment area of $\sim 251 \mathrm{~km}^{2}$. The Petit lac is fed by three main river systems that drain across an extensive floodplain; the Bornette, the Ire and Eau Morte-St Ruph. The Eau Morte is the largest of the three draining $~ 54 \%$ of the Petit Lac catchment, with an altitudinal drop of $\sim 1800 \mathrm{~m}$ (Foster et al 2003). Precipitation in the catchment, 
while highly variable is not seasonal, with mean monthly values (over the past 321 years) ranging between $0 \mathrm{~mm}$ and $228 \mathrm{~mm}$, alongside a few exceptional months beyond this range (Figure 2: Casty et al, 2005). Mean (monthly) temperatures are seasonally variable ranging between a summer high of $20^{\circ} \mathrm{C}$ and winter low of $-7^{\circ} \mathrm{C}$. Only January has a median monthly temperature below zero. Thus there is a short winter period when precipitation falls primarily as snow, with a strong dependency upon elevation.

\section{An Environmental History of the Lac d'Annecy catchment}

The Lac d'Annecy catchment has been permanently occupied since the Neolithic with only sporadic occupation prior to this (Crook et al., 2004; Della Casa, 2005). A progressive increase in human activity resulted in significant changes to the hydro-geomorphic system through a combination of land cover change and river channel/floodplain modifications (e.g. Crook et al., 2004; Dearing et al., 2001). The initial phase of agricultural development spans the Bronze, Iron and Roman periods and is characterised by lowland crop production and forest clearance at both low and high altitude (Crook et al., 2004, 2011). The onset of upland forest clearance is linked to the development of high altitude alpages for grazing starting in the Bronze / Iron Age (Crook et al., 2011). A similar pattern of upland clearance is recorded at upland sites across the European Alps at this time (e.g. Carrier 1932; Wick and Tinner 1997; Tinner et al., 1999; Rösch et al., 1998; Gobet et al., 2003; Wick et al., 2003), where it is often coincident with enhanced soil erosion as a result of the fragile nature of the soils at this altitude (e.g. Crook et al., 2004 ; Jacob et al., 2009).

Upland destablisation is seen to intensify with the onset of the Roman period $(\sim 120 \mathrm{BC}$ and $260 \mathrm{AD}$ ) and the development of upland villa complexes that would later form into communes, such as the Sextinacus Villa, that is now the commune of Seythenex (Crook et al., 2004). In the lowlands the intensification of agricultural production necessitated the large-scale drainage of marshland for farming, with the Romans focusing initially on the Eau Morte flood 
plain (e.g. Boisonnade 1937; Crook et al., 2004). The intensity of agricultural activity increases significantly during the Carolingian Dynastic period $(\sim 500-\sim 1000$ AD) with the building of a Benedictine Monastery at Talloires in AD 879. The Cistercians followed in AD 1132, establishinga monastery at Tame. A key feature of both monastic orders was the exploitation of land for agricultural use (Grande and Delatouche 1950; Crook et al., 2004). The Benedictines were the first group to actively clear and develop the uplands for summer grazing across what is now the Parish of Montmin. The Cistercians followed a similar pattern opening up the upland areas across the west of the catchment for agro-pastoral activities and settlement (Crook et al., 2004). Despite the loss of a significant area of upland forest, the environmental impact is thought to have been minimal as a result of the approach that the monasteries took to farming; particularly their attempts to retain soil fertility and reduce erosion rates (Crook et al., 2004).

With the transition into the Middle Ages ( 1000 - 1450 AD), the monastic approach to farming proved untenable. A rapidly expanding catchment population led to the development of marginal land across the catchment, kick-starting a long term trend of accelerating environmental degradation (Crook et al., 2002; 2004). Soil erosion became a widespread issue across the uplands, whilst on the valley floor a rapid decline in soil fertility was noted (Crook et al., 2004). A combination of plagues, wars and deteriorating climatic conditions led to several phases of reduced population pressure throughout the $15^{\text {th }}$ Century. The net effect was a contraction in agricultural lands, reduced agricultural output and the abandonment of marginal land in the catchment. In many areas erosion rates declined and soil fertility increased (Crook et al., 2004). The Catchment population continued to fluctuate throughout the Savoy Period ( AD 1450 1860), with similar consequences.

Environmental pressures peaked again in the $18^{\text {th }}$ Century, when arable farming fell into decline, with reduced soil fertility, increased flood damage and further land abandonment. Historical records point to widespread evidence for increased flooding and soil degradation across the catchment over the next 200 years (Crook et al., 2002, 2004, 2011; Mougin, 1914). The 
impact of flooding across the catchment was exacerbated by continued clear-felling across the catchment, a practice that peaked in $1840 \mathrm{AD}$ when forest cover declined to $<3500$ ha from a high of 6157 ha in 1730 (Crook et al., 2002, 2004).

By the start of the $20^{\text {th }}$ Century, successive flood remediation schemes had modified all three river systems and many of the upland torrent systems, which had either been straightened, deepened and where necessary dyked (e.g. Crook et al., 2002, 2011). The main river systems are now confined in their lower reaches; with reduced storage capacity across the floodplain and overbank deposition minimal. As a result the majority of the river sediment load is deposited directly into the lake (e.g. Dearing et al., 2001; Stanley and Jorstad 2004; Welsh et al., 2009; Crook et al., 2011). Over this same time period, forest cover has increased dramatically from $1850 \mathrm{AD}$ onwards with the area of modern forest cover equal to the levels recorded in the $\mathrm{AD}$ 1730 survey (Crook et al., 2002); an example of a modern forest transition in a high-income country (Lambin and Meyfroidt, 2010).

Today, the modern environment is under increasing pressure from farmers, foresters, tourism and the leisure industry that frequently have mutually incompatible aims for development. The environmental stress points have shifted away from geomorphic processes and flood control to maintaining water quality as the result of nutrient enrichment from agricultural intensification and domestic and industrial effluent. Despite the size of the lake, the increase in nutrient enrichment after AD 1900 was significant enough to impact the structure of planktonic food webs in the lake (e.g. Pergaet al., 2012). Although compared to a number of other large alpine lakes, Annecy is still one of the cleanest lakes in the region due to careful water management (Kaiblingeret al., 2009).

\section{Methodology \\ The proxy sediment record}

This study is based in part on the existing proxy record for LA13, a 8.15m Kullenberg sediment 
core recovered from the centre of the Petit Lac (Dearing et al 2001; Noel et al 2001). The upper most sediment record was not recovered in LA13 and the last few centuries of the record were lost. To extend the record through to the present day, the LA13 record was combined with a short overlapping sequence (SCLA13, $0.7 \mathrm{~m}$ ), recovered at the same time as the long core but was not used in the previously published study. The two cores were cross-correlated on the basis of their mineral magnetic records to produce a composite core record (LA13C) of $8.55 \mathrm{~m}$.

The range of analyses carried out on LA13 by Dearing et al., (2001) and Noel et al.,(2001) were replicated for SCLA13. All sub-samples were weighed prior to freeze-drying to calculate down core variation in water loss and bulk density. A full suite of magnetic measurements was then undertaken following Walden et al., (1999). Magnetisation and remanence measurements were carried out on a Molspin vibrating magnetometer (VSM) using the LOOP 2 routine at low $(1 \mathrm{mT}$ and $5 \mathrm{mT})$ and high $(800 \mathrm{mT}$ and $1000 \mathrm{mT}) \mathrm{AC}$ field strengths, using a suite of reverse fields. The relative contribution of Fe-bearing paramagnetic minerals was determined by the high field $(800 \mathrm{mT}$ and $1000 \mathrm{mT})$ susceptibility as a proportion of the low field (1 $\mathrm{mT}$ and $5 \mathrm{mT})$ susceptibility (PARA\%). The presence of haematite and goethite rich samples was determined using isothermal remanences at backfields of $1000 \mathrm{mT}\left(\mathrm{HIRM}_{\mathrm{H}}\right)$ and $300 \mathrm{mT}$ $\left(\mathrm{HITM}_{\mathrm{G}}\right)$ supported by low temperature remanence measurements (e.g. France, 1997). This suite of magnetic parameters has previously been used to discriminate different sediment sources within the Annecy catchment (Dearing et al., 2001): PARA\% (unweathered marls / limestones), $H_{I R M_{G}}$ (high altitude valley soils), HIRM $($ medium altitude soils) and Soft \% (low-mid altitude surface soils). Discrimination of the various sources contributing to the organic carbon content of the sediment record (soil, geological and aquatic) was undertaken following Noel et al. (2001) and included both chemical (Total Organic Carbon (TOC), pyrolisis, hydrogen index, LOI) and petrographic analyses. Pollen analysis was undertaken on $1-2 \mathrm{~cm}$ contiguous samples, and prepared following standard laboratory procedures (e.g. Faegri and Iversen, 1989).

Geochronological control for the LA13C was secured through a combination of absolute 
dating techniques $\left({ }^{210} \mathrm{~Pb}\right.$ and $\left.{ }^{14} \mathrm{C}\right)$ and the correlation between magnetic and palynological proxy data. Nine radiocarbon age determinations were obtained using terrestrial plant macrofossils (wood and leaves). These macrofossils were processed at the Beta Analytic and French laboratories, with all age determinations measured by accelerator mass spectrometry. Conventional ${ }^{14} \mathrm{C}$ ages were calibrated using the calibration curve of Reimer et al (2009) and the computer program OxCal (v4.10, Bronk Ramsey (2008). Radiocarbon results are quoted in accordance with the Trondheim international standard (Stuiver and Kra 1986); age ranges are quoted at $95 \%(2 \sigma)$ confidence interval (Table 1). The uppermost $1 \mathrm{~m}$ was analyzed for ${ }^{210} \mathrm{~Pb}$, ${ }^{137} \mathrm{Cs}$ and ${ }^{241} \mathrm{Am}$ using direct gamma assay. ${ }^{210} \mathrm{~Pb}$ radiometric dates were calculated using CRS and CIC dating models where appropriate (Appleby and Oldfield 1978); results were validated against ${ }^{137} \mathrm{Cs} /{ }^{241} \mathrm{Am}$ stratigraphical records to provide ages for the upper $23 \mathrm{~cm}$ back to AD 1954 (Table 1).

Further chronological control was achieved by correlation of magnetic proxy data between LA13C and the GLA profile sampled from the Grand lac d'Annecy (Nomade, 2005). A robust chronology has been produced from the Grand Lac sequence from annual laminations. Comparison of the SIRM stratigraphy between LA13 and GLA reveals a strong correspondence (Table 1) with a striking similarity to other Annecy sediment cores (Higgitt et al., 1991). Events observed in the pollen sequence are well represented in other pollen records from the region including the decline in Abies ( $4000-4400 \mathrm{BP})$, and the first appearance (2000-1800 BP) and rise to prominence (1200-800 BP) of Juglans.

To assess the robustness of the chronology, all the age control and errors have been incorporated in a sequence model and tested for conformability using OxCal (v4.10, Bronk Ramsey, 2008). The sequence model (Figure 3) shows good overall agreement between geochronological results and stratigraphy $(\mathrm{A}=109.4 \%)$. To achieve this level of agreement, only one outlier (2310 $\pm 70 \mathrm{BP}$ at $840 \mathrm{~cm}$ depth) had to be excluded from the analysis (Figure 3). The conformability of pollen and magnetic marker horizons with radiocarbon dates suggests that some 
of the problems often associated with carbonate catchments (e.g. artificially old ages owing to hard-water and residual carbon) have been circumvented through the use of plant macrofossils. The accepted age information was used to construct an age-depth model for the lake sediment sequence (Figure 3). Pollen markers were excluded from this process owing to the imprecise nature of the age control, although they are in line with the age-depth relationship.

Mean sediment accumulation rates (SAR) per year $\left(\mathrm{cm} \cdot \mathrm{yr}^{-1}\right)$ and sediment loadings were calculated over the length of the core in 100 to 1000 year time-slices. Total sediment mass deposited each year was calculated as measured mass multiplied by the area of the lake $(6.25$ $\mathrm{km}^{2}$ ). Sediment loadings were then converted to total sediment production per year per $\mathrm{km}^{2}$ by dividing by the catchment area $\left(170.4 \mathrm{~km}^{2}\right)$. For this calculation the Petit lac was treated as a separate basin with negligible sediment exchange with the Grand lac. The lake sediments are principally detrital in origin (Dearing et al.,2001; Foster et al., 2003) allowing the use of SAR as a proxy for allocthonous sediment load.

\section{Statistical Analysis}

Previous work in the Lac d'Annecy has clearly shown that human activity has had an observed quantified impact upon catchment dynamics. What we have hitherto not been able to discern is a signal of precipitation change upon catchment dynamics. To address this issue we focused on the primary landscape proxies (Soft, $\mathrm{HIRM}_{\mathrm{G}}, \mathrm{HIRM}_{\mathrm{H}}, \mathrm{PARA} \%$ and TOC) on the assumption that these proxies for erosion and deposition would normally vary synchronously with multi-annual (cyclical) changes in precipitation (allowing for some lagged time interval between climate forcing and landscape response(s)). Such a spatially synchronous signature will contrast with one created by human activities, which should have a more variable signature as disruption occurs sporadically in time and space.

In comparing our proxy records against precipitation data we focus on two aspects of the data, a) the cyclical nature of climate data and thus on a hypothesised cyclical impact upon the 
proxies; and b) the likelihood that our landscape proxies would take some unknown number of years to respond to changing precipitation regimes. Lagged proxy response times were estimated using cross-correlation, which quantifies the similarity between two waveforms (signals) as a function of a time-lag applied to one of the signals. It is not a classic correlation technique such as Pearsons or Spearmans but when normalised to range between -1 and 1 can be interpreted in much the same way. Next the frequency domain of the data was explored using cross-spectral analysis. The cross-spectral density can be thought of as a Fourier transform of the crosscovariance function (Chatfield, 2004). It enables one to 'correlate' between frequency peaks in the autospectrum of each time-series.

Significance levels in our spectral and cross-correlation data were calculated using a Monte Carlo approach. This involved randomising each dataset set, calculating the crosscorrelation or cross-spectra and then iterating 5000 times. In doing so we 'respected' the structure of our data whilst exploring the full range of permutations that might arrive by random chance. For the cross correlated data we used the 2 sigma standard deviation of these 5000 results as the significance level at each lagged interval. The iterated randomised data returned from crossspectral analysis is non-parametric so is this instance we used the $99^{\text {th }}$ percentile of the 5000 results as our significance level. We choose the $99^{\text {th }}$ percentile as a conservative interpretation of significance in a non-parametric dataset.

Our aim was to test the null hypothesis that there is no significant correlation between the pattern of precipitation change (direction and magnitude) and the pattern of change in our landscape proxies. In rejecting this hypothesis we could reasonably infer that precipitation is a significant driver of catchment dynamics. However, seasonal temperature variability is a complicating factor in this assumption. In Annecy (non-seasonal) precipitation falls as snow during winter months (Figure 2a). This must impart some seasonality to the landscape response to changes in long-term precipitation, for example, due to spring floods driven by snowmelt. Whilst the seasonality of a landscape response is largely irrelevant to our analysis, which focuses on 
proxy landscape records that are integrated over multi-annual timescales, it is logical for us to demonstrate (where possible) that our proxies are sensitive to monthly precipitation if we are to conclude that there is a precipitation signal in the stratigraphic record. Therefore in the following analysis we use the modelled 321 year (monthly) precipitation record of Casty et al., (2005) as well as a 3850 yr multi-annual proxy-precipitation created by Charman et al. (2006; 2009).

The Casty et al data are compiled from instrumental and documentary evidence and are available at monthly resolution in $0.5^{\circ} \times 0.5^{\circ}$ grid squares covering central Europe from $1659-$ 2000 AD. We extracted the $45.75 \mathrm{~N} / 6.25 \mathrm{E}$ grid square over Annecy from this dataset.We then down-sampled each column of monthly data to a 4 year resolution to match the maximum resolution of our (lake core) proxy data, after first applying a 4 year moving window to smooth the data. This down-sampling also necessitated us deleting the oldest 20 years of precipitation data because our proxy landscape data changes to a resolution $>4$ years beyond this point. All data were linearly detrended and expressed in standard deviation units.

To investigate our hypothesis over longer (millennial) timescales we use the bog surface wetness (BSW) record of Charman et al., (2006); we focus on this UK because no suitable long termclimate record is currently available for the Annecy region. This is a single UK-wide integrated record compiled from multiple UK bogs covering the period $4000 \mathrm{BC}$ to $1995 \mathrm{AD}$. We focus on the last 3850 years of this record as it offered the best resolution. These data are already detrended and expressed in units of standard deviation so we simply resampled at 25year resolution to create constant intervals.

Charman et al., (2009) discussed the interpretation of BSW data concluding that it is most sensitive to precipitation, with summer temperature having an important secondary effect. BSW records throughout NW Europe change at similar times and seem to be controlled by a common climatic forcing, namely the North Atlantic Multidecadal Oscillation (NAO) (Barber and Charman, 2003; Barber, 2006; Hughes et al., 2006; Sutton and Hodson, 2005; Charman et $a l ., 2010)$. The regional nature of this climate forcing means that it is reasonable for us to use it as 
a proxy for a fluctuating precipitation in the French Alps, i.e. both locations are sensitive to the same regional fluctuations in climate that have occurred through the late Holocene. We tested this assertion by comparing average monthly precipitation patterns between the UK as a whole (downloaded from the UK Met office website; http://www.metoffice.gov.uk/climate/uk/datasets/Rainfall/date/UK.txt) and Geneva (40km North of Annecy) between 1910 and 2011 AD (ECA\&D; http://eca.knmi.nl). We could not directly compare the Charman precipitation record with the $20^{\text {th }} \mathrm{C}$ Geneva record because of its low resolution. Somewhat surprisingly annual precipitation in the UK and at Geneva is significantly (Spearman) correlated (0.36). More importantly the cyclicity of annual precipitation in the UK and Geneva evidences significant cross-spectra (at 95\% sig.) (Figure 2c). Breaking precipitation down into monthly time-series shows that the dominant correlating periodicities lie in February, September and December (Figure 2c). Interestingly these 4-10 year periodicities match the NAO, offering good support for common climate forcing in the UK and Annecy. It is important to stress here that this comparison is confined to the last century; at the lower $(>1 / 100 \mathrm{yr})$ frequencies most relevant to this study other months might also share common climate frequencies. Indeed this is what we find in the results sections. Nevertheless, it is clear the UK and Annecy precipitation records are sensitive to the same multi-annual periodicities thereby justifying our use of the Charman et al., (2006) BSW dataset.

\section{Results and Interpretation}

\section{The sediment record}

The key elements of the proxy environmental record for LA13C are summarised in Figures 4a and $\mathrm{b}$. The proxy record is curtailed to match the timespan covered by the Charman et al., (2006; 2009) precipitation data set. The proxy record broadly conforms to the existing historical record for the catchment, reinforcing the role anthropogenic activity has had driving catchment processes 
over the Late Holocene. The record is dominated by a pronounced increase in sediment accumulation rates (SAR) /sediment yields (SY) from the Bronze Age (SAR $\sim 0.5 \mathrm{~g} \mathrm{~cm}^{3} \mathrm{yr}^{-1}: \mathrm{SY}$ $30 \mathrm{t} \mathrm{km}^{2} \mathrm{yr}^{-1}$ ) through into the modern Era (SAR $\sim .5 \mathrm{~g} \mathrm{~cm}^{3} \mathrm{yr}^{-1}: \mathrm{SY} 160 \mathrm{t} \mathrm{km}^{2} \mathrm{yr}^{-1}$ ), reflecting a long-termtrend of increasing erosion rates in the catchment (Figure $4 \mathrm{a}$ and $\mathrm{h}$ ). The changing pattern of sedimentation in the lake occurs against a backdrop of changing land cover characterised by periods of forest clearance (AP curve) coincident with the start and expansion of agricultural activity across the catchment (e.g. Juglans and Crop plants).

The first cereal grains are noted in the Iron Age preceded by a steady decline in AP through the Bronze Age. Low AP values point to, major woodland clearance phases in the Roman/Carolingian period (Figure 4b) and the Savoy/Modern Era (Figure 4i). Agricultural taxa are a permanent feature of the pollen record from the Roman period onwards. The Early land cover changesin the Iron Age are coincident with a sharp rise in soil derived organic matter entering the lake (Figure 4c). There is also a gradual rise in the contribution of soil derived from the high altitude valleys $\left(\mathrm{HIRM}_{\mathrm{G}}\right)$ at a time when the high altitude alpage were being developed for the first time (Figure 4d). Significant spikes in Soil OM and TOC are also noted for the other two major clearance phases.

The observed changes in SAR/sediment yield and the observed episodes of land cover change are paralleled by significant changes in sediment source over the Late Holocene. After the increase in the Iron Age, High Altitude Valley soils $\left(\mathrm{HIRM}_{\mathrm{G}}\right)$ again increase in significance from the Middle Ages onwards, reflecting the clearance of land for pasture (Figure $4 \mathrm{~d}$ and $\mathrm{k}$ ). In the Modern Era, the rise in $\mathrm{HIRM}_{\mathrm{G}}$ after 1890AD is coincident with low AP value suggesting these peak sediment yields are likely have resulted from the last major phase of forest clearance in the catchment. The contribution of soil from Medium-High valleys $\left(\mathrm{HIRM}_{\mathrm{H}}\right)$ remain significant throughout the record (Figure $4 \mathrm{e}$ and 1) although there is a marked shift at the start of the Carolingian Dynasty and a pronounced spike centered on 1910AD that is coincident with an equally sharp rise in TOC and Soil OM (Figure 4j). The most pronounced sediment source 
changes are noted for the Low-Mid Altitude Valley Soils (Soft\%) the contribution of which increases significantly in the Coralingian Dyansty. The timing of this rise is coincident with the development of the lower lying areas of the catchment by the monasteries. The sharp rise in SOFT $\%$ in the last 50 years, suggests the low - mid altitude valleys are again increasing in significance as a sediment source to the lake. The rise in SOFT\% is mirrored by rising soil OM values and also aquatic OM (Figure 4b) indicative of cultural eutrophication.

The final sediment source tracer, PARA\% is thought to reflect the in-wash of unweathered limestones and marls presumably transported during high energy flood events in the bedrock river channels in the Eau Morte and Ire catchments (e.g. Dearing et al 2001). The pattern of change is not as pronounced as other markers, but there appear to have been a significant decline in the contribution of unweathered limestone's and marls with the transition into the Carolingian Dynasty. Comparable values are also recorded over the last 300 years and may impact reflect the increased flood control measured in place across the catchment by this time, although clearly high-energy floods remain a feature of the hydro-geomorphic system over the entire Late Holocene period.

\section{Statistical analysis of proxy records}

In analysing the proxies $\left(\mathrm{HIRM}_{\mathrm{G}}, \mathrm{HIRM}_{\mathrm{H}}\right.$, SOFT and TOC, PARA\%) we choose to work at two different temporal resolutions covering two different time spans. This enabled us to test whether the landscape proxies correlate with precipitation over both centaury and millennial timescales; ideally we would have used a single high-resolution millennial long precipitation dataset but none exist. The maximum resolution of our landscape proxy data is 4-years and this is the resolution we use when drawing comparisons with the Casty et al., (2005) 321 year precipitation data. To perform a similar comparison over longer timescales we used the Charman et al., (2006) $3850 \mathrm{yr}$ long precipitation data; for this purpose we down-sampled/ interpolated our geomorphic-proxy data and Charman et al's data to a $25 \mathrm{yr}$ resolution. Thus in the following paragraphs each 
analysis is performed twice with the added complication that we also analyze monthly precipitation over the shorter 321 year period: see methods.

We first calculated the Spearman rank correlation coefficient (at a 4-year resolution) between each geomorphic proxy and the 321 year precipitation record of Casty et al., (2005). Only one of the proxies significantly correlated with precipitation $(\mathrm{TOC}=-0.28)$, while generally correlating more strongly with each other (Table 2). Given the obvious inter-dependence between each of these proxies we choose to combine them into a reduced dimension dataset using principal component analysis (PCA). At both resolutions each PCA axis accounted for similar variability: respectively at $4 / 25$ years PCA $1=36 \% / 33 \%$, PCA $2=27 \% / 27 \%$, PCA3 $=20 \% / 21 \%$.In order to determine which, if any, of the PCAs correspond to the long-term precipitation record we performed a cross spectrum analysis between the proxies and precipitation: see methods. We found a significant $(99 \%)$ correspondence between the precipitation and PCA2 spectra over both 3850 and 321 year time spans (Figure 5). PCAs 1 and 3 also display significance but to a far lesser degree. The common periodicities in these datasets are $>291$ years in the long 3850 record and $>32$ years in the shorter term 320 year record (Figure 5). The use of a maximum 4-year resolution precludes identification of shorter annual periodicities that might be related to the NAO. However, the high-resolution data (Casty et al. 2005) data did allow us to compare monthly precipitation against each PCA to determine which months might best explain variability in the landscape proxies. The strongest monthly relationships are found between January-March but all 4 seasons evidence statistically significant months (Figure 5b). This is good evidence that variability in precipitation is driving the landscape-dynamics proxies.

We used cross-correlation to determine if the proxies for landscape dynamics lag in their response to precipitation change. Given that PCA2 shows the strongest cross-spectra (Figure 5) we focused on this axis. There are many weak but statistically significant cross-correlations with precipitation over the past 3850 year (e.g. 350, 850 and 1175 years: Figure 6a). Similar but slightly stronger correlations are observed over the past 321 years, where both decadal and 
centennial lags are observed (Figure 6b). When the monthly precipitation data are summed to give total annual precipitation, significant cross-correlation remains at a 36 year lag with a crosscorrelation of 0.28 (Figure $6 \mathrm{~b}$ ). The closeness of this lagged annual relationship to April (at a 28 year lag) suggests that April dominates the annual signal. This observation is consistent with the recognised importance of spring floods to Annecy landscape dynamics (Foster et al 2003).

\section{Discussion}

We have shown that the five proxies for landscape dynamics $\left(\mathrm{HIRM}_{\mathrm{G}}, \mathrm{HIRM}_{\mathrm{H}}\right.$, SOFT, TOC and PARA\%) relate, albeit weakly, to long-medium term precipitation patterns. The strongest monthly relationships between precipitation and landscape dynamics are found between JanuaryMarch but all four seasons have statistically significant months (Figure 5). It is beyond the scope of this paper to resolve the detailed causal relationships between each month, concerned as we are with annual-millennial timescales, but the correlating cross-spectra during winter months is confounding given that precipitation would fall as snow during these months (Figure 2b). We here speculate that this relationship is due to the depth of snowpack created and the corresponding size of spring floods in April, the month that dominates the annual cross-correlation signal.

Regional climate phenomena such as the Atlantic multi-decadal oscillation appear to be at least partly responsible for landscape dynamics at Lac d'Annecy during the late Holocene. Comparison between $20^{\text {th }}$ century precipitation in the UK and Geneva clearly show significant correlating periodicities in the 2-10 year range (Figure 2c) consistent with a regional NAO signal. These periodic changes in precipitation are also reflected in the long term sediment record. The landscape proxies (PCA2) share significant correlating periodicities with UK and local precipitation (Figure 5). The effect of periodic changes in precipitation on landscape dynamics is also observed in the cross-correlation analysis, which shows numerous (lagged) cross-correlations between precipitation and PCA 2 (Figure 6). These wide ranging cross-correlations, ranging from 
zero years to centuries and beyond, are likely a reflection of sediment 'smearing'. River sediment typically moves downstream in waves characterized by relatively long periods of sediment storage (e.g. in alluvial terraces) followed by brief bursts of bedload transport. This transport mechanism can stretch the sedimentary response to precipitation across decades and centuries. Moreover, Benda and Dunne (1997) have shown that in a catchment similar to Annecy a single pulse of accelerated hillslope erosion can produce multiple solitary pulses of sediment that migrate downstream over centuries. This type of multi-phase response is a likely reason why we see such a wide range of lagged responses to precipitation change, i.e. no single lag interval represents a single erosion event. It is important to stress that despite evidence to support 'smearing of environmental signals' the effect of precipitation variability is still recognizable in the sedimentary record, albeit stretched over multiple timescales.

The presence of a weak but significant precipitation signal in the lac d'Annecy sediments implies that the processes of sediment transport and deposition are of insufficient magnitude and/or frequency to effectively 'shred' the precipitation signal. Recent modelling work had suggested that environmental signals cannot survive 'filtering' by non-linear transport processes (Van de Wiel and Coulthard, 2007, 2010; Jeromack and Paola, 2010). However, our results are not necessarily in conflict given that Jeromack and Paola (2010) also argued that signals of sufficiently low frequency would survive non-linear filtering. Thus we interpret our results to indicate that 4 year integrated records are of sufficiently coarse resolution to effectively average out the effects of shorter-term SOC transport processes, while also allowing us to identify the effect of environmental 'smearing' across decades to centuries. This is encouraging as it supports the widespread application of palaeo-environmental techniques that typically operate at multiannual resolutions.

\section{Conclusions}


The assessment of Holocene sedimentary records is often hampered by an antagonistic interplay between climate change and anthropogenic activity, which operate over similar spatial and temporal scales. In this study we have for the first time to used a combination of principal component and spectral analysis and cross-correlation to clearly discern a climate signal in a catchment heavily impacted by human activities throughout the late Holocene. These activities first began impacting geomorphic processes during the Late-Bronze/Early Iron Age, probably linked to the development of upland Alpage. This initial phase was then followed by a long term increase in sedimentation accumulation rates and sediment yields, that rise from $\sim 0.5 \mathrm{~g} \mathrm{~cm}^{3} \mathrm{yr}^{-}$ ${ }^{1}\left(30 \mathrm{t} \mathrm{km}^{2} \mathrm{yr}^{-1}\right)$ at the start of the Bronze Age to over $\sim 4.5 \mathrm{~cm}^{3} \mathrm{yr}^{-1}$ in the Modern Era equivalent to $160 \mathrm{t} \mathrm{km}^{2} \mathrm{yr}^{-1}$. This pronounced rise in sedimentation is driven by the long-term modification of the hydro-geomorphic system through a combination of land cover change and river channel/floodplain modifications.

The results of the statistical analysis indicate for the first time that regional climate phenomena such as the Atlantic multi-decadal oscillation are partly responsible for landscape dynamics at Lac d'Annecy, during the late Holocene. The Lac d'Annecy landscape typically requires decades, or longer, to respond to changes in precipitation, reflecting the stochastic nature of river sediment storage and transport. The use of a 4 year integrated lake core records appears to effectively attenuate the 'signal shredding' effect of shorter-term internally generated sediment transport processes. However, the lake record of climatically-induced geormorphic processresponses is weak compared to the impact of human activities, which clearly dominate the sedimentary record. 


\section{Acknowledgments}

This project was funded by the Leverhulme Trust (Grant No F/25/BQ). The reconstructed water table record for Northern England Peatlands was accessed through the NOAA website (Charman, D.J., and D. Hendon, 1999, Reconstructed Water Table Depths in Northern England Peatlands, IGBP PAGES/World Data Center A for Paleoclimatology Data Contribution Series \#1999-059. NOAA/NGDC Paleoclimatology Program, Boulder CO, USA). Logistical help in the field was provided by Fernand Bertier and Gez Foster, whilst Sandra Mather and Sue Rouillard provided invaluable help with the figures. Dan Charman, Bob Jude, Sue Franklin, Peter Hamilton and Malcolm Young are thanked for their assistance in the laboratory and discussion of the data. Finally three anonymous reviewers are thanked for their insightful comments on the first version of this manuscript. 


\section{REFERENCES}

Appleby PG and Oldfield F (1978) The calculation of lead-210 dates assuming a constant rate of supply of unsupported ${ }^{210} \mathrm{~Pb}$ to the sediment. Catena 5: 1-8.

Barber, K.E., 2006. Peatland records of Holocene climate change. In: Elias S (ed.)

Encyclopedia of Quaternary Science. Elsevier: Oxford, 1884-1895.

Barber KE, Charman DJ (2003) Holocene palaeoclimate records from peatlands. In: Mackay AW, Battarbee RW, Birks HJB, Oldfield F (eds.) Global Change in the Holocene. Edward Arnold: London, 210-226.

Benda L and Dunne T (1997) Stochastic forcing of sediment routing and storage in channel networks. Water Resources Research 33: 2865-2880.

Boisonnade P (1937) Life and work in medieval Europe (fifth to fifteenth centuries). Kegan Paul : London.

Bronk Ramsey C (2008) Deposition models for chronological records, Quaternary Science Reviews 27: 42-60.

Carrier EH (1932) Water and grass. Christophers : London.

Casty C, Wanner H, Luterbacher J, Esper J, Böhm R (2005) Temperature and precipitation variability in the European Alps since 1500. International Journal of Climatology 25: 1855-1880.

Charman DJ, Blundell A, Chiverrell RC, Hendon D and Langdon PG (2006) Compilation of nonannually resolved Holocene proxy climate records: stacked Holocene peatland palaeo-water table reconstructions from northern Britain. Quaternary Science Reviews 25: 336-350.

Charman DJ, Barber KE, Blaauw M, Langdon PG, Mauquoy D, Daley TJ, Hughes PDM, Karofeld E (2009) Climate drivers for peatlandpalaeoclimate records.Quaternary Science Reviews 28: 1811-1819.

Charman DJ (2010) Centennial climate variability in the British Isles during the mid-late Holocene.Quaternary Science Reviews 29: 1539-1554.

Coulthard TJ and Van De Wiel MJ (2007) Quantifying fluvial non-linearity and finding self organized criticality? Insights from simulations of river basin evolution. Geomorphology 91: 216-235.

Crook DS, Siddle DJ, Jones RT, Dearing JA, Foster GC and Thompson R (2002). Forestry and flooding in the Annecy Petit Lac Basin, 1730-2000. Environment and History 8: 403-28.

Crook DS, Siddle DJ, Dearing JA and Thompson R (2004) Human Impact on the Environment in the Annecy Petit Lac catchment, Haute-Savoie: A documentary approach. Environment and 
History 10: 247-284.

Crook DS, Dearing JA, Jones RT and Elvin M (2011) An inter-continental comparison between the environmental histories of two Lake Catchment systems in montane environments of France and South West China. Water History Journal 3: 95-120.

Dearing JA (1979) The application of magnetic measurements to studies of particulate flux in a lake-watershed ecosystem. Ph.D. Thesis : University of Liverpool, $235 \mathrm{pp}$.

Dearing JA andZolitschka B (1999) System dynamics and environmental change: an exploratory study of Holocene lake sediments at Holzmaar, Germany.The Holocene 9: 531-540.

Dearing JA, Hu YQ, Doody P, James PA and Brauer A (2001) Preliminary reconstruction of sediment-source linkages for the past $6000 \mathrm{yrs}$ at the Petit Lac d'Annecy, France, based on mineral magnetic data. Journal of Paleolimnology 25 : 245-258.

Dearing JA and Oldfield F (2002) The role of human activities in past environmental change.In:AlversonK, Bradley RS and Pedersen TF (eds.). Paleoclimate, global change, and the future. Springer Verlag: 143 - 162.

Dearing JA and Jones RT (2003) Coupling temporal and spatial dimensions of global sediment flux through lake and marine sediment records. Global and Planetary Change 39: 147-168.

Dearing JA, Battarbee RW, Dikau R, Larocque I and Oldfield F (2006) Human-environment interactions: learning from the past. Regional Environmental Change 6: 1-16.

Della-Casa PH (2005) Lithic resources in the early prehistory of the Alps. Archaeometry 47: 222234.

Faegri K and Iversen J (1989) Textbook of pollen analysis, 5th Edition, Wiley: Chichester

Foster GC, Dearing JA, Jones RT, Crook DS, Siddle DJ, Harvey AM, James PA, Appleby PG, Thompson R, Nicholson J and Loizeaux J-L (2003) Meteorological and land use controls on geomorphic and fluvial processes in the pre-Alpine environment: an integrated lake-catchment study at the Petit Lac d'Annecy. Hydrological Processes 17: 3287-3305.

France D (1997) The mineral magnetic characterisation of goethite and haematite in soils and sediments. Ph.D. Thesis: University of Liverpool, 194 pp.

Ganti V, Straub KM, Foufoula-Georgiou E, Paola C (2011) Space-time dynamics of depositional systems: Experimental evidence and theoretical modeling of heavy-tailed statistics: Journal of Geophysical Research, doi:10.1029/2010JF001893

Gobet E, Tinner, W, Hochueli PA, van Leeuwen, JFNH, Amman B (2003) Middle to Late Holocene vegetation history of the Upper Engadine (Swiss Alps): the role of man and fire. Vegetation History and Archaeobotany 12:143-163.

Grand R and Delatouche R 1950 Agriculture au Moyen Age de la fin de $l \square$ 'empire Romain au 
XVI siècle Tome III. Paris: E. de Boccard.

Higgitt SR, Oldfield F and Appleby PG (1991) The record of land use change and soil erosion in the Late Holocene sediments of the Petit Lac d'Annecy, eastern France. The Holocene 1: 14 18.

Hooke RLB (2000) On the history of humans as geomorphic agents. Geology 28: 843-846.

Hughes PDM, Blundell A, Charman DJ, Bartlett S, Daniell JRG, Wotjatschke A, Chambers FM, 2006. An 8500 cal. year multi-proxy climate record from a bog in eastern Newfoundland: contributions of meltwater discharge and solar forcing. Quaternary Science Reviews 25: 12081227.

Jacob J, Disnar J-R, Arnaud F, Gauthier E, Billaud Y, Chapron E and Bardoux G (2009) Impacts of new agricultural practices on soil erosion during the Bronze Age in the French Prealps. The Holocene 19: 241 - 249.

Jerolmack DJ and Paola C (2010) Shredding of environmental signals by sediment transport: Geophysical Research Letters 37 : L19401, doi:10.1029/2010GL044638.

Kaiblinger C,Anneville O,Tadonleke R, RimetF, Druart JC, Guillard J, Dokulil MT (2009) Central European water quality indices applied to long-term data from peri-alpine lakes: test and possible improvements. Hydrobiologia 633: 67-74.

Lambin EF and Meyfroidt P (2010) Land use transitions: Ecological feedback versus exogenous socio-economic dynamics. Land Use Policy 27: 108-118.

Mougin P (1914) Les torrents de Savoie: Grenoble.

Noel H, Garbolino E, Brauer A, Lallier-Verges E, de Beaulieu JL and Disnar JR (2001) Human impact and soil erosion during the last $5000 \mathrm{yrs}$ as recorded in lacustrine sedimentary organic matter at Lac d'Annecy, the French Alps. Journal of Paleolimnology 25: 229-244.

Nomade J (2005) Chronologieetsédimentologie du remplissage du lac d'Annecy depuis le Tardiglaciaire: implications paléoclimatologiquesetpaléhydrologiques. Unpublished $\mathrm{PhD}$ thesis, Laboratoire de Géodynamique des Chaines Alpines:Université Joseph Fourier, Grenoblepp 181.

Perga M-E, Desmet M, Enters D and Reyss JL (2010) A century of bottom-up- and top-downdriven changes on a lake planktonic food web: A paleoecological and paleoisotopic study of Lake Annecy, France. Limnology and Oceanography 55:803 -816.

Reimer PJ, Baillie MGL, Bard E, Bayliss A, Beck JW, Blackwell PG, BronkRamse, C, Buck CE, Burr GS, Edwards RL, Friedrich M, Grootes PM, Guilderson TP, Hajdas I, Heaton TJ, Hogg AG, Hughen KA, Kaiser KF, Kromer B, McCormac FG, Manning SW, Reimer RW, Richards, DA, Southon JR, Talamo S, Turney CSM, van der Plicht J, Weyhenmeyer CE (2009) IntCal09 
and Marine09 radiocarbon age calibration curves, 0 - 50,000 years cal BP. Radiocarbon 51: 1111-1150.

Reinhardt LW, Jerolmack D, Cardinale B, Vanacker V and Wright J (2010) Dynamic Interactions of Life and its Landscape: feedbacks at the interface of geomorphology and ecology. Earth Surface Processes and Landforms 35: 78-101.

Rösch M (1998) The history of crops and crop weeds in south-western Germany from the Neolithic period to modern times, as shown by archaeobotanical evidence. Vegetation History and Archaeobotany7: 109-25.

Stanley and Jorstad, TF (2004)Direct Sediment Dispersal from Mountain to Shore, with Bypassing via Three Human-Modified Channel Systems to Lake Annecy, SE France. Journal of Coastal Science 20: 958 - 969.

Stuiver M and Kra RS (eds.) (1986) Calibration issue, Proceedings of the 12th International ${ }^{14} \mathrm{C}$ conference.Radiocarbon 28: 805-1030.

Sutton RT andHodson DLR (2005) Atlantic Ocean forcing of north American and European summer climate. Science 309: 115-118.

Thorndycraft V, Hu Y, Oldfield F, Crooks PRJ and Appleby PG (1998) Individual flood events detected in the recent sediments of the Petit Lac d'Annecy, eastern France. The Holocene 8: 741746.

Tinner W, Hubschmid P, Wehrli M, Ammann B, Conedera M (1999) Long-term forest fire ecology and dynamics in southern Switzerland.Journal of Ecology 87: 273-289.

Van De Wiel MJ and Coulthard TJ (2010) Self-organized criticality in river basins: Challenging sedimentary records of environmental change. Geology 38: 87-90.

Walden J, Oldfield F and Smith JP (eds.) (1999) Environmental Magnetism, a practical guide. Technical Guide, No. 6.Quaternary Research Association: London.

Welsh KE, Dearing JA, Chiverrell RC and Coulthard TJ (2009) Testing a cellular modelling approach to simulating late-Holocene sediment and water transfer from catchment to lake in the French Alps since 1826. The Holocene 19: 783-796.

Wick L and Tinner W (1997) Vegetation changes and timberline fluctuations in the Central Alps as indicators of Holocene cli-matic oscillations.Arctic and Alpine Research 29: 445-458.

Wick L, Leeuwen JFN van, Knaap WO van der, Lotter AF (2003) Holocene vegetation development in the catchment of Sägistalsee (1935 m a.s.1.), a small lake in the Swiss Alps. Journal of Paleolimnology 30: 261-272

Wilkinson BH and McElroy BJ (2007) The impact of humans on continental erosion and sedimentation. GSA Bulletin 119: 140-156. 
FIGURE CAPTIONS

Figure 1: Topographic map of the Petit Lac d'Annecy catchment. The major commune boundaries and population centres are marked on the map along with the major river tributaries and the location of the sediment core LA13C (LA13 and LA13SC).

Figure 2: Monthly (A) precipitation and (B) temperature in the Annecy region over the past 321 years (from Casty et al., 2005) plus (C) a comparison between spectral patterns of precipitation in the UK and Geneva between 1910 and 2011 AD. Significant precipitation cross spectra between the UK and Geneva are shown over both monthly and annual intervals; both 95\% and $99 \%$ significance levels are also shown. All data was detrended, centred and expressed in terms of standard deviation units prior to Fourier transformation.

Figure 3: Integrated geochronological 'Sequence' (Bronk Ramsay, 2008) and age-depth models for the LA13C core profile. The model integrates age information gathered by:- ${ }^{210} \mathrm{~Pb}$ (grey bars) and ${ }^{14} \mathrm{C}$ (black shade) absolute dating techniques; correlation of magnetic stratigraphy (grey shade) with the annually laminated Grande Lac d'Annecy (Nomade, 2005) and correlation of pollen marker horizons with the regional vegetation history (white hatch). The radiocarbon ages are the probability distribution of the calibration relationship, with the other chronological markers given a Gaussian distribution based on the likely or measurement error (Table 1). The structure of the model is with the ages in stratigraphical order inside the Sequence, which is defined as a group of events (ages) or phases that are known to follow one after another with no possibility of overlap. The model results show good overall agreement index (A) between the geochronological results and stratigraphy, $\mathrm{A}=109.7 \%$, which exceeds the $60 \%$ acceptance threshold (Bronk Ramsay, 2008). The percentages show the agreement index for each individual age horizon. Any dates that were excluded from the 'Sequence' model are prefixed with '*', and typically have a low $(<60 \%)$ agreement index for that individual date. The age-depth model (black line) is a cubic polynomial fit to the ${ }^{14} \mathrm{C},{ }^{210} \mathrm{~Pb}$ and magnetic chronological markers (with individual Agreement indices greater than 60\%), also showing the 90-95 prediction error (red lines).

Figure 4: Palaeoenvironmental reconstruction of the Petit Lac d'Annecy catchment based on the core analysis of LA13C. Data from two periods 1700 BC to 2000 AD (panels A - G) and the last 
3 centuries, AD1700 - 2000 (Panels H - N) are presented, sub-divided into 7 historical periods following Crook et al., 2002; 2004 and 2010. Selected pollen profiles are used to reconstruct past land cover change including forest cover (Total Arboreal pollen excluding Alnus (AP\%)) and agricultural activity (e.g. Juglans and Crops (including Cereals, Cannabis, Castanea) (Panels A, B and $\mathrm{H}$ ) that is compared to forest inventory records $(\mathrm{H})$. The pollen record is compared to records of Total Organic Carbon (TOC) (b, i) and the presence of Soil OM (c) and aquatic Organic Matter (i). Selected magnetic profiles are also presented reflecting the varying sources of sediment to the lake from distinctive soils around the catchment following Dearing et al, (2001) $(\mathrm{c}-\mathrm{h}$ and $\mathrm{j}-\mathrm{m})$. Calculated mass accumulation rates and sediment yields for the catchment are presented $(g, n)$.

Figure 5: Cross-spectra between precipitation and (PCA axes of) the landscape dynamics proxies $\mathrm{HIRM}_{\mathrm{G}}, \mathrm{HIRM}_{\mathrm{H}}$, SOFT, TOC and PARA\%. Significance is denoted by $99 \%$ confidence lines beyond which correlations are unlikely to arise purely by chance (see methods). (A) Shows significant cross-spectra between average UK precipitation and landscape-PCAs in 25 year intervals over the past 3850 years; based on data from Charman et al. (2006). PCA2 shows the strongest cross-spectra but PCA3 is also significant. (B) Shows significant cross-spectra between monthly precipitation in the Annecy region and landscape-proxies in 4-year intervals over the past 321 years; based on data from Casty et al. (2005). Most of the significant monthly precipitation cross-spectra are with PCA2. The gray shaded 99\% significance area encompasses all of the unique significance lines associated with each month. All cross-spectra above the shaded area are statistically significant. All data was detrended, centred and expressed in terms of standard deviation units. Only those cross-spectra that proved significant are shown here.

Figure 6: Cross-correlations showing the lagged response of landscape-proxies to changes in precipitation at Annecy. Significance is denoted by 95\% confidence lines beyond which correlations are unlikely to arise purely by chance. (A) Cross correlations between Charman et al., (2006) UK precipitation and PCA2 in 25 year intervals over the past 3850 years. Weak but significant lagged landscape responses to precipitation change are seen over both centaury and millennial scales. (B) Cross-correlations between Casty et al. (2005) Annecy-region precipitation in 4 year intervals over the past 321 years. Weak but significant lagged landscape responses to precipitation change are observed over decadal $(0,28 \& 36$ years) to centaury timescales. Only those months that show both; a) a significant cross-spectra between precipitation and PCA 2 in Figure 5; and b) significant cross-correlations with PCA2 are shown here, i.e. Feb, March, April and August. 
Table 1: The composite core chronology for LA13C a combination of ${ }^{14} \mathrm{C}$ AMS radiocarbon dates in terrestrial macrofossils (A); ${ }^{210} \mathrm{~Pb}$ age determinations for the upper sediments (B); Crosscorrelated dates transferred from Nomade (2005) core taken in the Grand Lac, based on the mineral magnetic record $(\mathrm{C}, \mathrm{D})$ and regional vegetation markers recorded in pollen diagrams across the Pre-Alps.

Table 2: Spearmans correlation coefficients for each of the landscape proxies $\left(\mathrm{HIRM}_{\mathrm{G}}, \mathrm{HIRM}_{\mathrm{H}}\right.$, SOFT, TOC and PARA\%) and the 321 year Casty et al (2005) precipitation record. Statistically significant correlations are highlighted in bold italics. All data was smoothed and either downsampled or interpolated to create a complete record at 4 year sample intervals. These data were detrended, centered and expressed in terms of standard deviation units. 


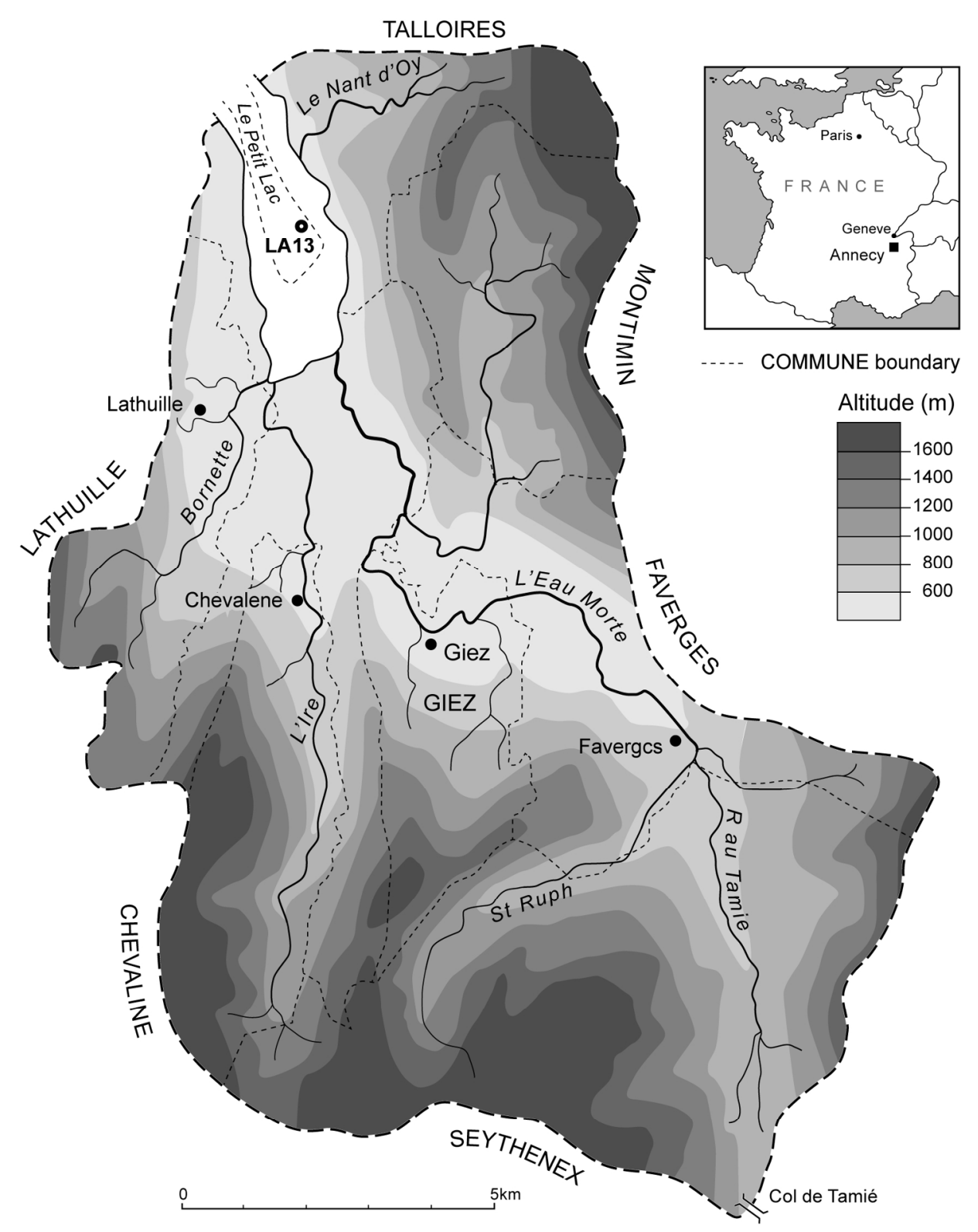

Topographic map of the Petit Lac d'Annecy catchment. The major commune boundaries and population centres are marked on the map along with the major river tributaries and the location of the sediment core LA13C.

$146 \times 186 \mathrm{~mm}(300 \times 300 \mathrm{DPI})$ 

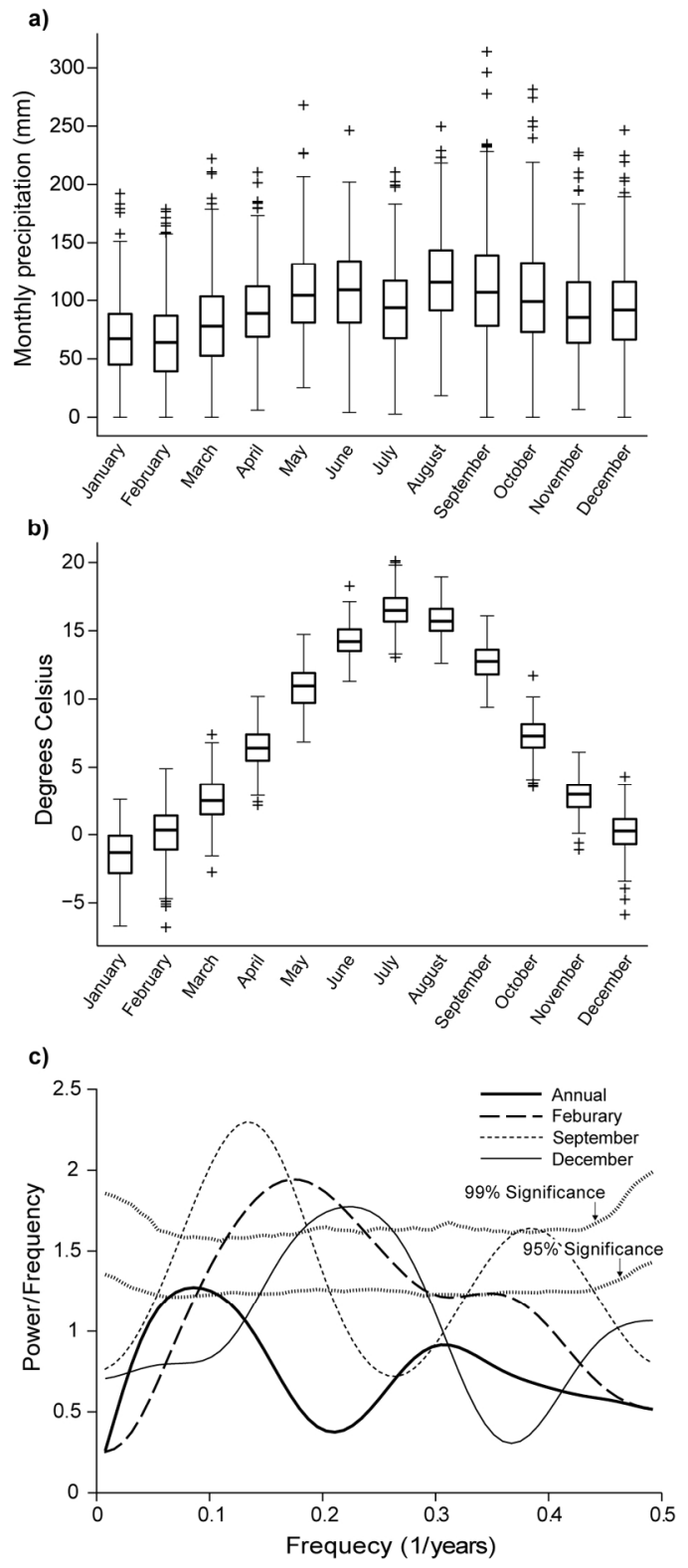

Monthly (A) precipitation and (B) temperature in the Annecy region over the past 321 years (from Casty et al., 2005) plus (C) a comparison between spectral patterns of precipitation in the UK and Geneva between 1910 and 2011 AD. Significant precipitation cross spectra between the UK and Geneva are shown over both monthly and annual intervals; both $95 \%$ and $99 \%$ significance levels are also shown. All data was detrended, centred and expressed in terms of standard deviation units prior to Fourier transformation. $80 \times 186 \mathrm{~mm}(300 \times 300 \mathrm{DPI})$ 


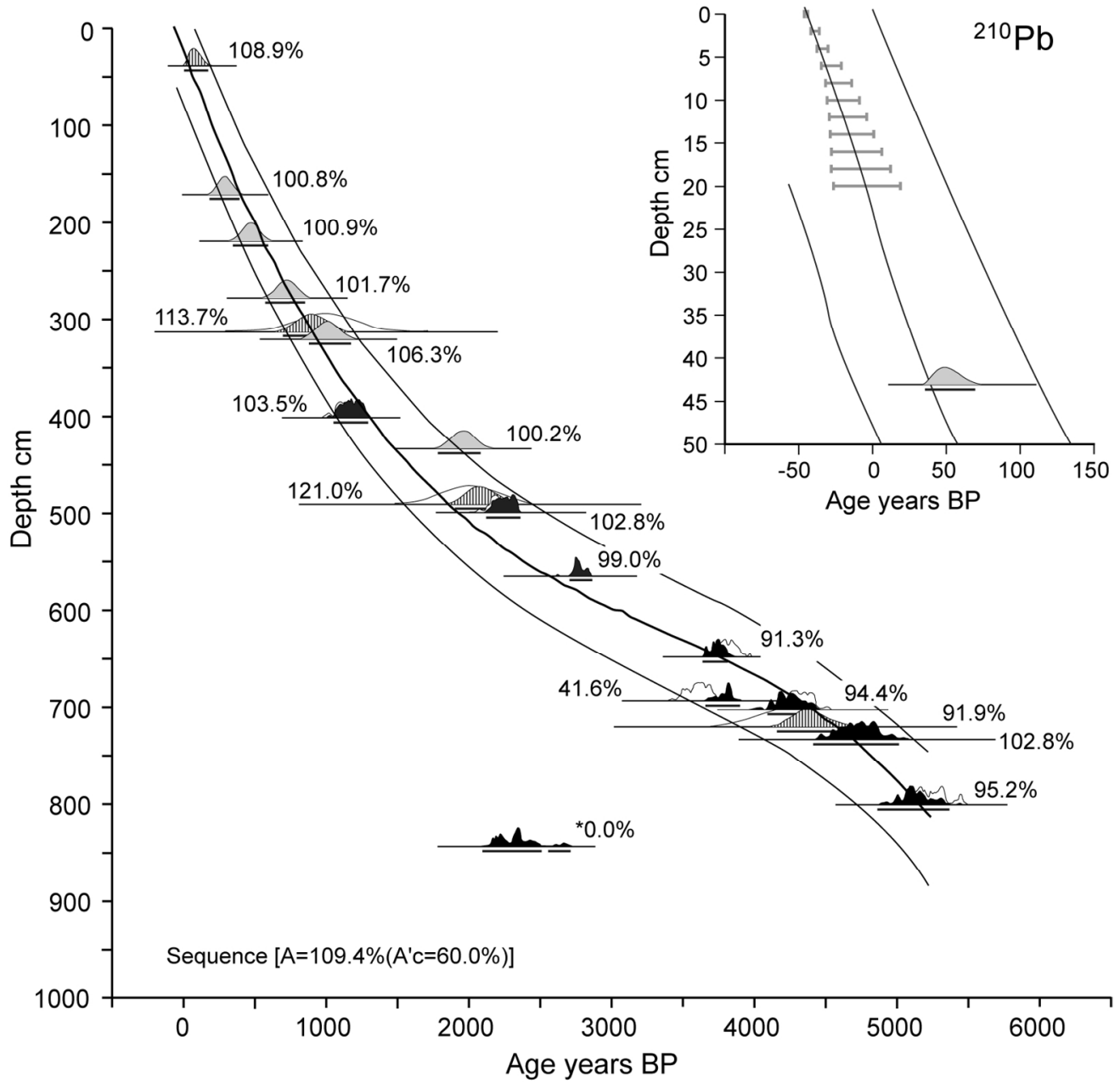

Integrated geochronological 'Sequence' (Bronk Ramsay, 2008) and age-depth models for the LA13C core profile. The model integrates age information gathered by:-210Pb (grey bars) and 14C (black shade) absolute dating techniques; correlation of magnetic stratigraphy (grey shade) with the annually laminated Grande Lac d'Annecy (Nomade, 2005) and correlation of pollen marker horizons with the regional vegetation history (white hatch). The radiocarbon ages are the probability distribution of the calibration relationship, with the other chronological markers given a Gaussian distribution based on the likely or measurement error (Table 1). The structure of the model is with the ages in stratigraphical order inside the Sequence, which is defined as a group of events (ages) or phases that are known to follow one after another with no possibility of overlap. The model results show good overall agreement index $(A)$ between the geochronological results and stratigraphy, $\mathrm{A}=109.7 \%$, which exceeds the $60 \%$ acceptance threshold (Bronk Ramsay, 2008). The percentages show the agreement index for each individual age horizon. Any dates that were excluded from the 'Sequence' model are prefixed with ' $*$ ', and typically have a low $(<60 \%)$ agreement index for that individual date. The age-depth model (black line) is a cubic polynomial fit to the $14 \mathrm{C}, 210 \mathrm{~Pb}$ and magnetic chronological markers (with individual Agreement indices greater than 60\%), also showing the 90-95 prediction error (red lines). $138 \times 134 \mathrm{~mm}(300 \times 300$ DPI $)$ 

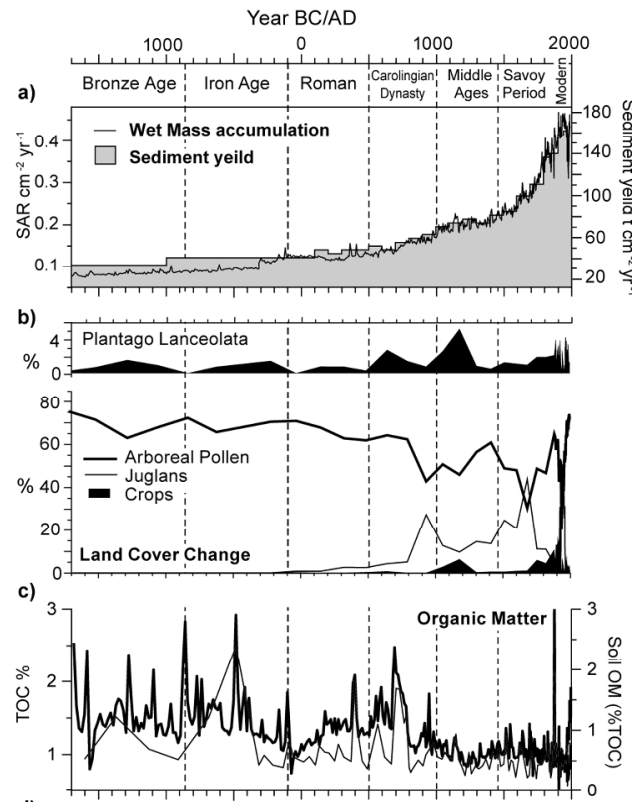

d)
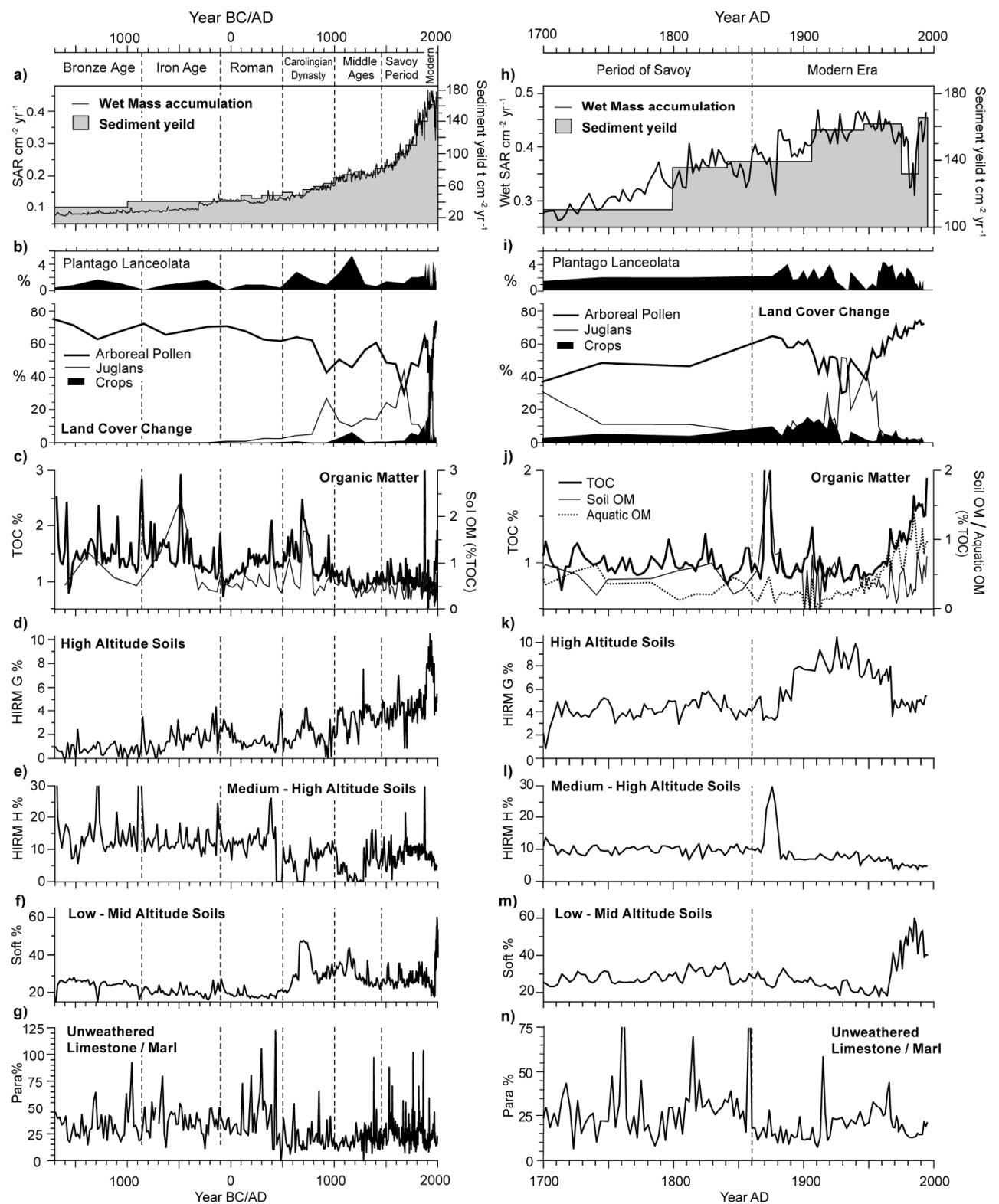

Palaeoenvironmental reconstruction of the Petit Lac d'Annecy catchment based on the core analysis of LA13C. Data from two periods 1700 BC to 2000 AD (panels A - G) and the last 3 centuries, AD1700 - 2000 (Panels H - N) are presented, sub-divided into 7 historical periods following Crook et al., 2002; 2004 and 2010. Selected pollen profiles are used to reconstruct past land cover change including forest cover (Total Arboreal pollen excluding Alnus (AP\%)) and agricultural activity (e.g. Juglans and Crops (including Cereals, Cannabis, Castanea) (Panels A, B and $\mathrm{H}$ ) that is compared to forest inventory records $(\mathrm{H})$. The pollen record is compared to records of Total Organic Carbon (TOC) (b, i) and the presence of Soil OM (c) and aquatic Organic Matter (i). Selected magnetic profiles are also presented reflecting the varying sources of sediment to the lake from distinctive soils around the catchment following Dearing et al, (2001) (c - h and j - m).

Calculated mass accumulation rates and sediment yields for the catchment are presented $(g, n)$. $179 \times 218 \mathrm{~mm}(300 \times 300 \mathrm{DPI})$ 

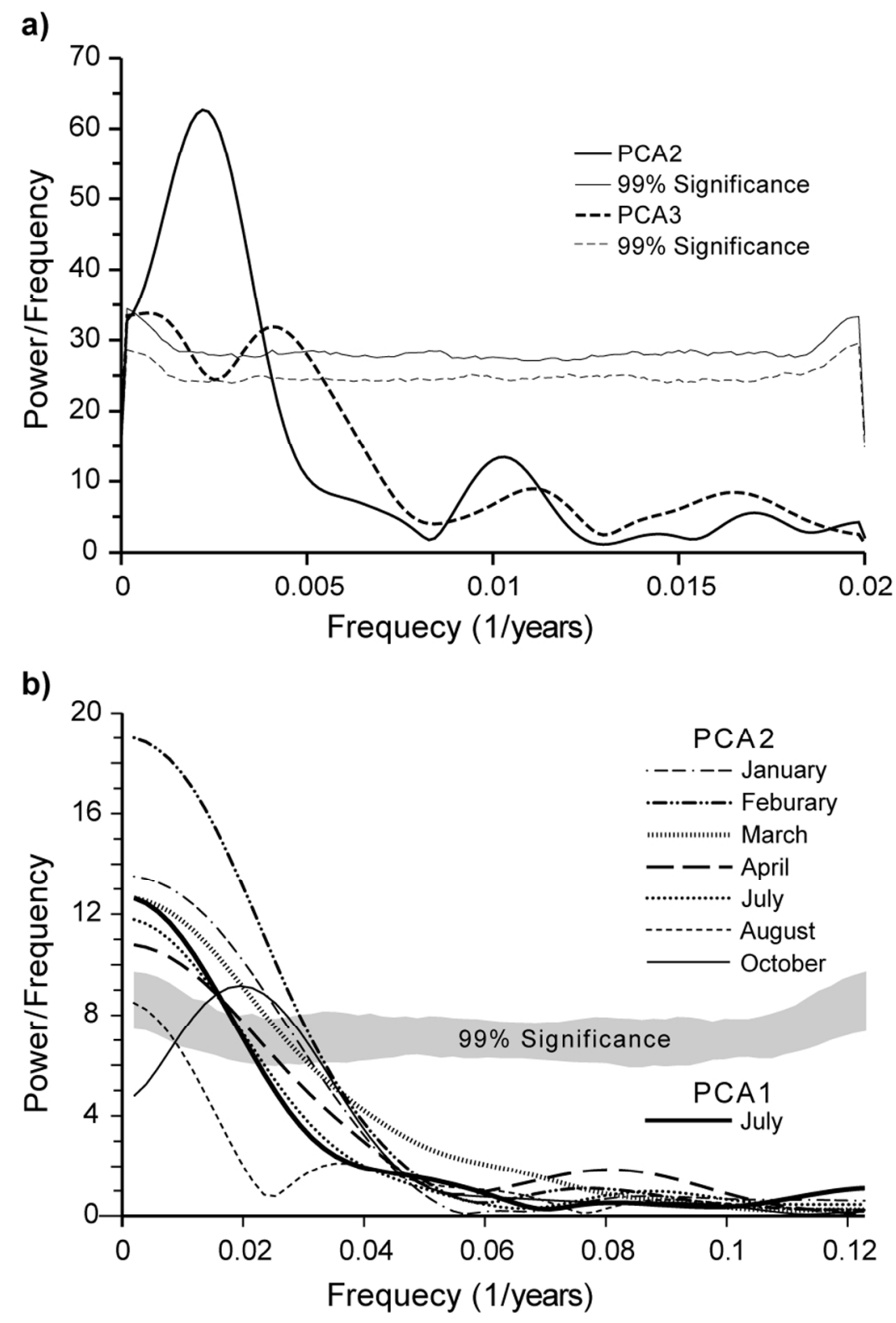

Cross-spectra between precipitation and (PCA axes of) the landscape dynamics proxies HIRMG, HIRMH, SOFT, TOC and PARA\%. Significance is denoted by $99 \%$ confidence lines beyond which correlations are unlikely to arise purely by chance (see methods). (A) Shows significant cross-spectra between average UK precipitation and landscape-PCAs in 25 year intervals over the past 3850 years; based on data from Charman et al. (2006). PCA2 shows the strongest cross-spectra but PCA3 is also significant. (B) Shows significant cross-spectra between monthly precipitation in the Annecy region and landscape-proxies in 4year intervals over the past 321 years; based on data from Casty et al. (2005). Most of the significant monthly precipitation cross-spectra are with PCA2. The gray shaded $99 \%$ significance area encompasses all of the unique significance lines associated with each month. All cross-spectra above the shaded area are statistically significant. All data was detrended, centred and expressed in terms of standard deviation units. Only those cross-spectra that proved significant are shown here. $76 \times 114 \mathrm{~mm}(300 \times 300 \mathrm{DPI})$ 


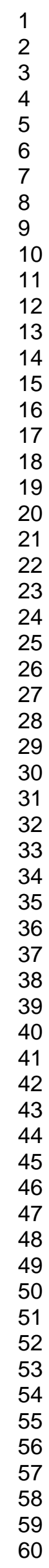

http://mc.manuscriptcentral.com/holocene 
a)

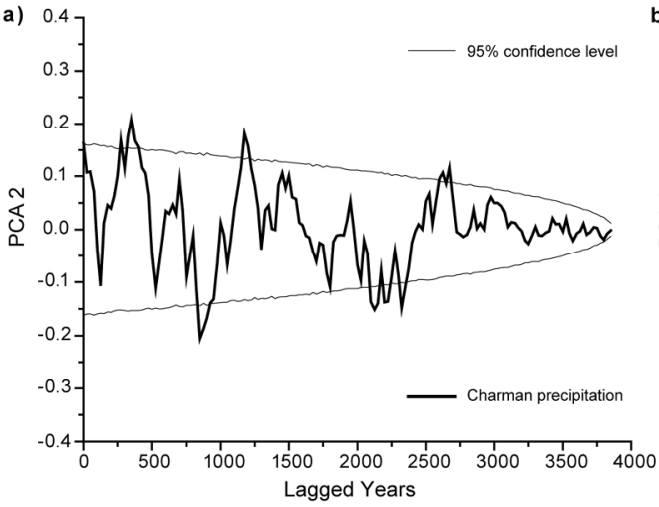

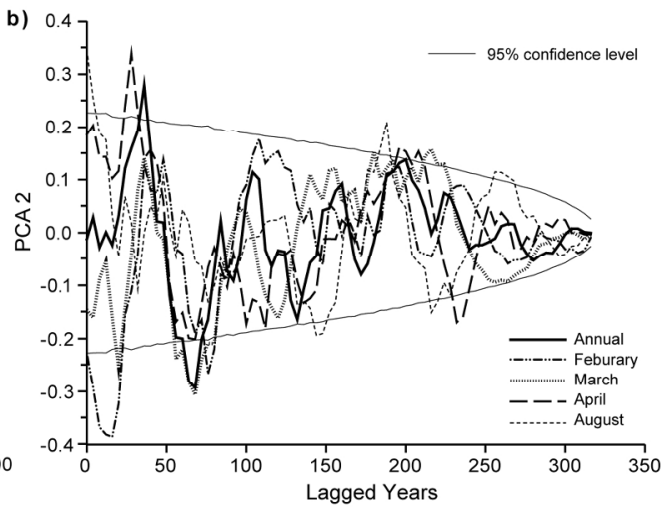

Cross-correlations showing the lagged response of landscape-proxies to changes in precipitation at Annecy. Significance is denoted by $95 \%$ confidence lines beyond which correlations are unlikely to arise purely by chance. (A) Cross correlations between Charman et al., (2006) UK precipitation and PCA2 in 25 year intervals over the past 3850 years. Weak but significant lagged landscape responses to precipitation change are seen over both centaury and millennial scales. (B) Cross-correlations between Casty et al. (2005) Annecy-region precipitation in 4 year intervals over the past 321 years. Weak but significant lagged landscape responses to precipitation change are observed over decadal $(0,28 \& 36$ years) to centaury timescales. Only those months that show both; a) a significant cross-spectra between precipitation and PCA 2 in Figure 5; and b) significant cross-correlations with PCA2 are shown here, i.e. Feb, March, April and August.

$172 \times 66 \mathrm{~mm}(300 \times 300 \mathrm{DPI})$ 
a)

\begin{tabular}{|c|c|c|c|}
\hline $\begin{array}{c}\text { Depth } \\
\text { on LA13 }\end{array}$ & Material & ${ }^{14}$ C Age (BP) & $\begin{array}{c}\text { Calibrated Age BP } \\
\text { (95\% confidence) }\end{array}$ \\
\hline 842 & Leaves & $2310 \pm 70$ & $2125-2410$ \\
\hline 804 & Wood & $4550 \pm 70$ & $4970-5220$ \\
\hline 736 & Wood in flood lamination & $4200 \pm 100$ & $4435-4705$ \\
\hline 702 & Wood & $3860 \pm 60$ & $4090-4260$ \\
\hline 694 & Wood & $3370 \pm 70$ & $3500-3640$ \\
\hline 649 & Wood & $3520 \pm 50$ & $3640-3785$ \\
\hline 565 & Wood & $2650 \pm 56$ & $2710-2790$ \\
\hline 500 & Wood & $2218 \pm 56$ & $2065-2210$ \\
\hline 400 & Wood & $1231 \pm 59$ & $1005-1150$ \\
\hline
\end{tabular}

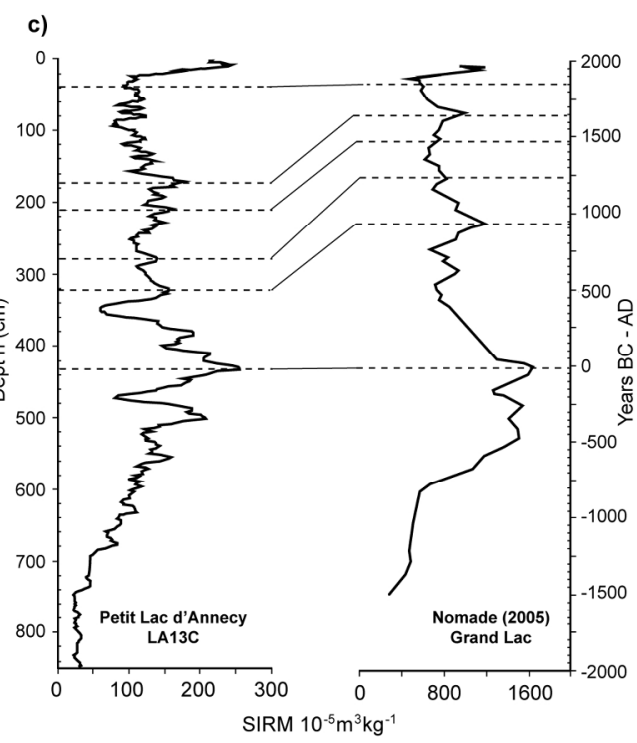

$177 \times 157 \mathrm{~mm}(300 \times 300$ DPI $)$

b)

d)

e)

\begin{tabular}{|c|c|c|}
\hline $\begin{array}{c}\text { Depth } \\
(\mathbf{c m})\end{array}$ & $\begin{array}{c}\text { 210PB } \\
\text { Age years AD }\end{array}$ & Age years ago \\
\hline 0 & 1995 & 0 \\
\hline 2 & 1989 & 6 \\
\hline 4 & 1984 & 11 \\
\hline 6 & 1978 & 17 \\
\hline 8 & 1973 & 22 \\
\hline 10 & 1970 & 25 \\
\hline 12 & 1967 & 28 \\
\hline 14 & 1964 & 31 \\
\hline 16 & 1961 & 34 \\
\hline 18 & 1958 & 37 \\
\hline 20 & 1954 & 41 \\
\hline
\end{tabular}

\begin{tabular}{|c|c|c|}
\hline $\begin{array}{c}\text { Depth } \\
\text { LA13 }\end{array}$ & $\begin{array}{c}\text { Age GLA } \\
\text { Years }\end{array}$ & $\begin{array}{c}\text { Estimated } \\
\text { error }\end{array}$ \\
\hline $38-40$ & AD 1880 & 50 \\
\hline $170-172$ & AD 1660 & 50 \\
\hline $220-222$ & AD 1480 & 60 \\
\hline $279-281$ & AD 1225 & 70 \\
\hline $320-322$ & AD 940 & 80 \\
\hline $430-434$ & 10 BC & 80 \\
\hline
\end{tabular}

\begin{tabular}{|c|c|c|c|}
\hline $\begin{array}{c}\text { Depth } \\
\text { on LA13 }\end{array}$ & $\begin{array}{c}\text { Age } \\
\text { Years AD/BC }\end{array}$ & $\begin{array}{c}\text { Estimated } \\
\text { error }\end{array}$ & Markers \\
\hline $315-320$ & 1000 & 200 & $\begin{array}{c}\text { Juglans rise to abundance } \\
\text { Medieval }\end{array}$ \\
\hline $490-500$ & 2000 & 200 & $\begin{array}{c}\text { Juglans first occurancc } \\
\text { Roman }\end{array}$ \\
\hline $715-725$ & 4200 & 200 & Abies decline \\
\hline
\end{tabular}

35

36 
Spearmans correlation coefficients for each of the landscape proxies (HIRMG, HIRMH, SOFT, TOC and PARA\%) and the 321 year Casty et al (2005) precipitation record. Statistically significant correlations are highlighted in bold italics. All data was smoothed and either down-sampled or interpolated to create a complete record at 4 year sample intervals. These data were detrended, centered and expressed in terms of standard deviation units. $121 \times 53 \mathrm{~mm}(300 \times 300 \mathrm{DPI})$ 